\title{
SPAS AND SENSIBILITIES: DARWIN AT MALVERN
}

\author{
Janet Browne
}

In 1842 when Captain Richard Claridge first described a new form of hydrotherapy to British patients ${ }^{1}$ there were only two places in England that could be visited in order to see what the system offered. ${ }^{2}$ Ten years later, however, despite scandals about the dramatic death of at least one aristocratic patient, ${ }^{3}$ there were 24 water-cure establishments in Britain and Ireland, many of which were famous enough to be known simply by the owner's name, ${ }^{4}$ and the water-cure had become an extraordinary social phenomenon noisily discussed in Punch $^{5}$ and other prominent

Janet Browne, MA, Ph.D., Darwin Letters Project, University Library, West Road, Cambridge, CB3 9DR.

${ }^{1}$ Richard T. Claridge, a captain in the Middlesex Militia, was a convert to the water-cure as practised by Vincent Priessnitz in Graefenberg, Silesia, at whose establishment he had taken the cure in 1840 . He recounted his experiences in public lectures, articles and books, and later believed that he had coined the word "hydropathy". He did not open a hydropathic centre of his own until 1848 and this was located in Grande-Chartreuse, not Britain. See Richard Claridge, Hydropathy; or, the cold water cure, as practised by Vincent Priessnitz, London, 1842; followed later by Facts and evidence in support of hydropathy; being the subject of lectures delivered in a tour through Ireland and Scotland, 1843, London, 1844; Cholera: its preventive and cure by hydropathy, London, 1849; and Every man his own doctor. The cold water, tepid water, and friction cure, as applicable to every disease to which the human frame is subject, London, 1849. Claridge was involved in a controversy about priority with Dr James Wilson of Malvern: they both believed they were the first to bring Priessnitz's water-cure to England. See Ernest Sackville Turner, Taking the cure, London, Michael Joseph, 1967, pp. 163-4.

${ }^{2} \mathrm{Dr}$ Joseph Weiss of Freidwaldau ran a centre at Stansteadbury in Hertfordshire. Another water-cure, run by Dr C. von Schlemmer, from Bavaria, operated at Ham Common, Surrey. According to Turner, op. cit., note 1 above, p. 163, there were at least 50 water-cure establishments in Germany alone. James Wilson settled in Malvern in June 1842, followed by James Manby Gully in October the same year. They opened for business soon afterwards. See Richard Metcalfe, The rise and progress of hydropathy in England and Scotland, London, Simpkin, Marshall, Hamilton, Kent \& Co., 1906, p. 63.

${ }^{3}$ Sir Francis Burdett, who had undergone hydrotherapy at Stansteadbury under Dr Edward Johnson in 1843 (Johnson's first year as proprietor), died in January 1844. Johnson faced public unease about the role of hydrotherapy in Burdett's death and issued a denial in The Times, 27 January 1844. Another incident featured Dr James Ellis of Sudbrook Park, Surrey, who faced a manslaughter charge in 1846 but was finally discharged. See Metcalfe, op. cit., note 2 above; Turner, op. cit., note 1 above, pp. 192-202.

${ }^{4}$ The following water-cure establishments have been identified as being in existence before 1850 (not in order of establishment; the names of practitioners are supplied if known; the list excludes resorts with mineral springs and spas): Malvern (J. M. Gully); Malvern (James Wilson); Cheltenham (James Freeman); Cheltenham (John Balbirnie); Umberslade Hall, Birmingham (Edward Johnson); Stansteadbury (Joseph Weiss; Edward Johnson); Ham Common (C. von Schlemmer); Ben Rhydding (William Macleod); Kirn, Scotland (Rowland East); Sudbrook Park (Joseph Weiss; James Ellis); Dunstable (Forbes Lawrie); Ramsgate (Thomas Smethurst); Ramsgate (Abraham Courtney); Harrow; Tunbridge Wells (G. H. Heathcote); Kingston (Foster M'Gee); Isle of Man; Cork (Richard Barter); Rothesay (William Paterson); Angusfield, Aberdeen (Alexander Monro); Cluny Hill, Forres (Calder); Ryde (Samuel Weeding); Grasmere (Stumm); Epsom, Surrey (Thomas Graham); Manchester (Joseph Constantine); Moor Park, Surrey (E. W. Lane).

${ }^{5}$ Douglas Jerrold, 'Life at the cold brandy-and-water cure', Punch, or the London charivari, 1846, 11: 243-4. The attribution to Jerrold is made by Walter Jerrold, Douglas Jerrold and 'Punch', London, Macmillan, 1910, p. 434. 


\section{Darwin at Malvern}

London journals. The plain, simple treatment meted out by the first and most famous pioneer of the water-cure, Vincent Priessnitz, at Graefenberg in Silesia, was by then hardly recognizable in the enthusiastic excesses of early Victorian therapy. More and more centres were established during the next three decades until many thousands of patients were passing through hydropathic doors each year in the 1870 s. $^{6}$ Even during the earlier period, at the pinnacle of Gully's and Wilson's reign at Malvern, James Manby Gully (1808-83) was treating about 50 residential patients a month, plus an equal number of out-patients living in rented accommodation. ${ }^{7}$ James Wilson (1807-67) could cope with nearer $120,{ }^{8}$ and the local guidebooks were happily trumpeting that these and nearby establishments were drawing some 6,000 visitors to the town each year during the watering season. ${ }^{9}$

Among these 6,000 visitors to Malvern were Charles Darwin and his family. In many respects, Darwin was a typical early Victorian patient and his voluminous correspondence $^{10}$ gives us a useful guide to what he, and other Malvern invalids, might have thought of the water-doctors and their therapy. Even though we know a great deal about spas and hydropathy in general, we still have little documentary information about the factors that may have been involved in the patients' decision to try the "cure" or what may have governed their choice of resort and actual doctor. Why Malvern instead of Ben Rhydding? Why Gully instead of Wilson? What did the nineteenth-century public expect from a spa and were their expectations fulfilled? Did customers like Darwin make return visits, or did they perhaps sample a large number of different centres? Darwin's experiences under Gully at Malvern, although only an isolated example, provide at least some practical resources on which these larger historical questions can be framed.

Few historians doubt that Darwin was ill, and whatever the ultimate cause or causes may have been, there is no question that he exhibited genuinely distressing

\footnotetext{
${ }^{6}$ Hydropathic centres in Malvern were drawing around 6,000 patients annually in and around 1861 . A local guidebook entitled Cross's historical handbook to Malvern ... A book for visitors, Malvern, [1864?], p. 136, records that "Had the census [of 1861] been taken in the 'Malvern season' the population would probably have been 12,000" instead of the usual 6,049. John Smedley's establishment at Matlock, capable of accepting 100 patients at a time, treated 3,000 individuals in 1876. See Kelvin Rees, 'Water as a commodity: hydropathy in Matlock', in Roger Cooter (ed.), Studies in the history of alternative medicine, London, Macmillan, 1988, p. 34. Some indication of the total numbers involved in hydrotherapy at home and in established centres is given by the sales figures of Gully's handbook on the subject. Eighty-five thousand copies of J. M. Gully, A guide to domestic hydrotherapeia, London, 1863, were sold by 1872 . See Rees, p. 34.

${ }^{7}$ Metcalfe, op. cit., note 2 above, pp. 69-70. The figure given by Charles Darwin when in Malvern in 1849 was nearer 60 patients. See F. H. Burkhardt and S. Smith (eds.), The correspondence of Charles Darwin, vols. 1-5 (1821-55), Cambridge University Press, 1983-9, vol. 4, p. 234.

${ }^{8}$ James Wilson and James Manby Gully, The dangers of the water cure and its efficacy examined and compared with those of the drug treatment of diseases ... with an account of cases treated at Malvern, and a prospectus of the water cure establishment at that place, London, 1843, Prospectus, p. 15. In the same work, Wilson recorded that he had treated 600 patients in his first year at Malvern (pp. 1, 6).

${ }^{9}$ Cross's Historical handbook, op. cit., note 6 above, p. 136.

${ }^{10}$ Correspondence, op. cit., note 7 above. The entire correspondence has been calendared in a summary form in F. H. Burkhardt and S. Smith (eds.), A calendar of the correspondence of Charles Darwin, 1821-1882, New York and London, Garland, 1985.
} 
symptoms. ${ }^{11}$ But this in itself does not explain his interest in water. Like others in his situation, he turned first to the professionals and sought out high-level, traditional medical advice, both from his father, an experienced and perceptive physician, and from his distant cousin, the London doctor and writer Henry Holland, ${ }^{12}$ as well as consulting the local practitioner and apothecary in Down village, where he lived, and even Sir Benjamin Brodie on occasion.

After Robert Waring Darwin died in the autumn of 1848, Darwin placed himself entirely in the hands of Henry Holland, and then, as his ill-health suddenly intensified, turned instead to solicit sympathy and medical advice from friends and relatives who also experienced similar Victorian maladies. He consequently heard of the Malvern water-cure, not through books, newspapers or advertisements, or through his doctor, but through the personal recommendation of his cousin and fellow invalid, William Darwin Fox. "Thank you much for your information about the water cure," wrote Darwin to Fox in February 1849.

I cannot make up my mind; I dislike the thoughts of it much-I know I shall be very uncomfortable there ... Can you tell me ( $\&$ I shd be much obliged sometime for an answer) whether either [of] your cases was dyspepsia, though Dr. Holland does not consider my case quite that, but nearer to suppressed gout. He says he never saw such a case, \& will not take [it] on him to recommend the water cure.-I must get Gully's Book. ${ }^{13}$

Swapping information like this was plainly such an integral part of Darwin's normal daily existence that it would require no further comment were it not for the fact that a great number of other potential water-patients also came to hear of Malvern through similar chains of letters and personal recommendations. The same kind of intimate network permeated intellectual and literary London, and undoubtedly ran through the larger world of fashionable society as well. Alfred Tennyson heard of Malvern from Henry Hallam, Arthur's surviving brother, who had taken the waters there, ${ }^{14}$ Charles Dickens and his wife Kate heard from Douglas Jerrold; ${ }^{15}$ Jerrold heard from Bulwer; Bulwer read about it in Claridge and later met Dr Wilson at a social event; ${ }^{16}$ Dickens told Wilkie Collins; ${ }^{17}$ and thus it went wheeling on through Victorian high society during the 1840 s and 1850 s. Gully and Wilson

\footnotetext{
${ }^{11}$ Ralph Colp, To be an invalid: the illness of Charles Darwin, University of Chicago Press, 1977, supplies information on Darwin's symptoms. Darwin's correspondence, particularly with his father, the Shrewsbury physician Robert Waring Darwin, indicates that his most common complaints were giddiness, nausea, retching, vomiting (during bad spells), boils and headaches. See Correspondence, op. cit., note 7 above, vols 3 and 4.

12 Payment for a medical consultation with Henry Holland is recorded in Darwin's account book for early January 1849. His account books are located at Down House, Downe, near Bromley, Kent.

13 Correspondence, op. cit., note 7 above, vol. 4, p. 209.

14 Robert B. Martin, Tennyson. The unquiet heart, Oxford, Clarendon Press, 1980; Elizabeth Jenkins, Tennyson and Dr. Gully, Tennyson Society Occasional Papers 3, Lincoln, 1974, p. 6.

15 Madeline House and Graham Storey (eds.), The Letters of Charles Dickens, vols. 1-6(1820-52), Oxford, Clarendon Press, 1965-88, vol. 4, p. 28; Dickens took his wife to receive treatment from Wilson in Malvern in March and April 1851, see ibid., vol. 6, p. 309.

${ }^{16}$ Edward Bulwer-Lytton, Confessions of a water-patient: in a letter to W. Harrison Ainsworth Esq., Editor of "The New Monthly Magazine", London, 1845, pp. 19-28.

17 Turner, op. cit., note 1 above, p. 178.
} 


\section{Darwin at Malvern}

evidently believed that the eminent men and women they so assiduously courted ${ }^{18}$ preferred to act on personal advice received from people they knew and trusted on the social grapevine. So, unlike other hydropathic doctors, they did not advertise directly, either in newspapers, literary weeklies or the medical journals; instead, they deliberately plugged into an efficient, pre-existing system of private contacts, public testimonies, and letters of recommendation, to which they added the judicious circulation of their own books in order to keep their names prominently before a specifically targeted section of the community. ${ }^{19}$

William Darwin Fox had encouraged Darwin to read Gully's book and we know from Darwin's correspondence that he did so. ${ }^{20}$ On the basis of a wide variety of case histories supplied there by Gully and price lists discreetly displayed at the back, he diagnosed his own condition, costed out the expenses and possible length of stay, rejected his earlier plan of an extended visit to Ramsgate for sea-bathing with the family, ${ }^{21}$ and ultimately announced that he had "resolved to go this early summer and spend two months at Malvern \& see whether there is any truth in Gully and the water cure: regular doctors cannot check my incessant vomiting at all." 22 It is clear that all the crucial decisions about trying the cure and for how long and where, were made by Darwin-the potential patient-without recourse to any professional opinion, including that of Gully himself. In Darwin's view, and probably in the eyes of others similarly circumstanced, Gully offered a medical service, the major elements of which were, by definition, controlled by the paying customers. For hydrotherapy was hardly compulsory. No one had to undergo treatment; no one had to visit Malvern or Stansteadbury; the more usual approach to chronic disease in these prosperous circles was, of course, to travel on the continent, as Tennyson and, more notably, Dickens preferred to do, even in many cases to pursue a grand cure along with their grand tour in Italy or elsewhere. Gully needed to smooth and flatter to ensure a steady flow of visitors to Malvern, whilst also providing medical assistance that was both desirable in the customers' eyes and efficacious. Darwin's and Gully's professional transactions therefore reflected the reassuringly familiar pattern of relations between

\footnotetext{
${ }^{18}$ Gully's taste for great men developed early: he had met Sir Walter Scott in Edinburgh during his time as a dresser on the wards in the Edinburgh Infirmary, 1826-9, and had cultivated the famous Liverpool banker William Roscoe as a patron. After moving into more fashionable practice in London, he printed for private circulation Lectures on the moral and physical attributes of men of genius and talent, London, 1836. In the same year he also wrote a stage play adapted from a Dumas novel, The lady of Belle Isle, or, a night in the Bastille, which was later produced in Drury Lane, in December 1839. Both Gully and Wilson were listed under the category "Gentry" in the Post Office Directory for Worcestershire, 1850, as was usual for society physicians, as opposed to the "Trades" index under "Physicians".

19 James Manby Gully, The water cure in chronic disease, London, 1846; James Wilson, A practical treatise on the cure of diseases by water, air, exercise and diet, London, 1842; Stomach complaints and drug diseases: their causes, consequences, and cure by water, air, exercise and diet, London, 1843; and The practice of the water cure, with authenticated evidence of its efficacy and safety, London, 1844. They also published a joint work, op. cit., note 8 above. The books published by Gully and Wilson mimic this personalized style of information: Wilson and Gully, op. cit., note 8 above, includes 70 authenticated cases and 28 letters from "patients who have experienced the effects of the water cure".

${ }^{20}$ Correspondence, op. cit., note 7 above, vol. 4, pp. 227, $229 \mathrm{n}$. 1. There is no direct evidence of a correspondence between Darwin and Gully, although Darwin's wife Emma stated that "Dr Gully writes like a sensible man", see ibid., p. 223.

21 Ibid., p. 150.

22 Ibid., p. 219.
} 


\section{Janet Browne}

patients and practitioners that had been mapped out in the previous century, and which still held firm in the early years of the nineteenth. The water-doctors may have offered "alternative" therapies located out on the radical fringe, ${ }^{23}$ but they certainly did not wish to frighten off patients by abandoning all that the public had come to expect of professional medical men. In many ways their relations with clients were entirely traditional, and they ran their establishments on a system of customer relations that very broadly resembled the state of affairs previously existing in private madhouses and rest homes in England before the Lunatic Asylums Acts of 1828 and 1845 tightened up the controls on admissions. Before 1845, anyone who had felt the need for private mental treatment and could pay for it was able to enter a house on a voluntary basis, and stay until they felt ready to leave. Yet after Shaftesbury's Asylum Bill, ${ }^{24}$ no one could enter a madhouse or asylum without being certified by at least two medical practitioners - a move intended to reduce the possibility of patients being falsely incarcerated but one which also removed all likelihood of voluntary admissions. Individuals such as Tennyson, who had experienced a nervous breakdown in 1843 and had placed himself in a private asylum run by Matthew Allen in Epping, ${ }^{25}$ were loath to pursue this kind of self-determining rest if it also required certification as insane. It seems very probable that the water-cure, coming so soon after these major medical reforms, provided a ready substitute for patients seeking voluntary, institution-based medical help during which they could still call the shots. Many of the early water-doctors were willing to take on responsibility for treating all kinds of "nervous" complaints that would previously have been the stock in trade of private asylums, and keen to maintain the pre-existing pattern of patient-doctor relationships.

Darwin arrived in Malvern in March 1849 and stayed until 30 June. Gully (plate 7) had set up his establishment here in 1842 , just a few months after his friend Wilson had purchased a large hotel and renamed it Graefenberg House, in honour of Vincent Priessnitz. Gully purchased Newby House, which he renamed Tudor House, and another large one called Holyrood House for his private residence. Then, as business expanded, he moved his family into a third, called Priory House, and merged the first two together as his hydropathic centre (plate 8), one house for men, the other for women residents, connected by a "bridge of sighs". ${ }^{26}$

But Darwin did not stay in this large medical establishment. Like many of Gully's patients, he took accommodation in Malvern in one of the large villas along the Worcester Road, ${ }^{27}$ and attended Tudor House as an out-patient. Really famous visitors like Tennyson or Carlyle were invited to stay at Priory House as Gully's

\footnotetext{
${ }^{23}$ Robin Price, 'Hydrotherapy in England, 1840-70', Med. Hist., 1981, 25: 269-80; Metcalfe, op. cit., note 2 above, pp. 58-76.

${ }^{24}$ Geoffrey B. A. M. Finlayson, The seventh Earl of Shaftesbury, 1801-1885, London, Eyre Methuen, 1981.

${ }^{25}$ Martin, op. cit., note 14 above.

${ }^{26}$ Phyllis G. Mann, Collections for a life and background of James Manby Gully M.D., Malvern, privately published, 1983.

27 "The Lodge" was owned by a Miss Hind. See Post Office Worcestershire Directory, op. cit., note 18 above.
} 


\section{Darwin at Malvern}

personal guests. ${ }^{28}$ Wilson, who lived in his own medical premises (plate 9), apparently arranged his affairs differently and, according to malicious gossip, preferred that only the seriously ill and more disfigured patients should live out, so that he would not have to sit next to them at dinner. ${ }^{29}$ For Darwin, the obvious advantages of a private house over the communal living of Tudor or Holyrood Houses were increased by the fact that he was allowed to retain several privileges that hydropathic residents missed, such as a 7 o'clock start to the day rather than being up at 5 , less closely supervised diets and, for him, the very real benefit of not having to dine and make conversation with all the other patients, even a little snuff-taking in the privacy of his own lodgings, although this was eventually disallowed. And of course, unlike almost all visitors to the largest hydropathic centres in Europe, Darwin was living in the company of his wife and children. More than this, the Darwins were accompanied by a retinue of servants, nursery maids, and the governess, Miss Thorley. Neither Emma Darwin nor the children took the cure at this time, though Gully claimed great success with female complaints and childhood diseases and even though Emma was soon unwell with morning sickness, ${ }^{30}$ but there was some talk that perhaps Darwin's younger sister Catherine might come and join him for therapy. ${ }^{31}$ Quite a lot of socializing and other normal household activity was evidently taking place in "The Lodge", and the usual routine continued sufficiently to welcome short visits paid to the house by one of Darwin's other sisters, Susan, ${ }^{32}$ and Emma's brother Hensleigh Wedgwood and his wife. ${ }^{33}$ Once again, to a certain degree, the patient was here allowed to choose his own way of following the cure and to regulate the pace of treatment. Family life continued and Darwin was still ostensibly in overall charge of his therapy.

Gully's regime was based on the idea that all chronic disorders were caused by a faulty supply of blood to the viscera and that the application of cold water to the skin would return the circulation to normal and alleviate the condition. ${ }^{34}$ In deliberate contrast to treatments based on the act of drinking water, as at Graefenberg and other important spas like Bath, Gully held to the idea that water was at its most effective if applied externally. At Malvern it was applied in a number of ways, principally as showers and baths, but also included a wide variety of specialized techniques such as wet-sheet packing and wrapping, steam baths, friction of the skin and rubbing, that were derived from Priessnitz's tubs and showers. ${ }^{35}$ These external treatments were reinforced by a routine of early rising, and a multitude of short walks on the Malvern Hills (plate 10) interspersed with plain food and water to drink. Everything was designed to fulfill Gully's promise of "pure air, pure water, and dietic rule".36

\footnotetext{
${ }^{28}$ Mann, op. cit., note 26 above. See also Jenkins, op. cit., note 14 above; Turner, op. cit., note 1 above, pp. 174-5.

29 Ibid., pp. 166-7.

${ }^{30}$ Correspondence, op. cit., note 7 above, vol. 4, p. 235, in which Darwin reports that Emma was in "her usual wretched state". Leonard Darwin was born on 15 January 1850.

31 Ibid., p. 225.

32 Ibid., p. 226, n. 8.

33 Ibid., pp. 245-6.

34 Gully, op. cit., note 19 above.

${ }^{35}$ Metcalfe, op. cit., note 2 above; Turner, op. cit., note 1 above. The treatments are fully described in Gully, op. cit., note 19 above, pp. 564-627.

36 Metcalfe, op. cit., note 2 above, p. 69.
} 
At Darwin's initial consultation, at a fee ${ }^{37}$ of two guineas-the cost of a whole week's treatment, as he reported in horror to William Darwin Fox-Gully told him that he was puzzled by his case, but agreed that dyspepsia was the culprit. ${ }^{38}$ Originally only a descriptive, functional term that meant simple indigestion, the word "dyspepsia" for Gully and other doctors of the mid-nineteenth century had come to include ideas of physical weakness, loss of appetite, and, most particularly, a depression of spirits, morbid despondency, and gloom. ${ }^{39}$ This combination of physical and psychological disorders was exactly the kind of illness that Gully claimed to cure: his therapeutic system placed great emphasis on relieving mental and physical discomfort by revitalizing the inner organs that were held to be the true seat of the disorder. Gully defined dyspepsia as "nervous indigestion". It was caused, he believed, by "a chronic excess and congestion of the blood in the . . . ganglionic nerves that surround and supply the stomach." 40 Moreover, people like Darwin, accustomed to a life of intense mental endeavour, were prone to conditions in which the activity of the brain set up and maintained nervous irritation that kept up the derangement of the stomach. "The close application of the mind to any one subject", Gully stated, "whether it be abstruse or superficial . . ranks among the frequent causes of nervous dyspepsia ... Intellectual labour and moral anxiety each or conjointly keep up the derangement of other parts." ${ }^{11}$ The analysis was simple: the digestive organs irritated the brain and spinal cord and these in turn irritated the stomach. As Darwin put it: he "thinks my head or top of spinal chord cause of mischief."42

Darwin's treatment therefore followed Gully's established practice for nervous dyspeptic conditions. A good deal of friction and rubbing with wet towels was used for the first ten days, until the patient was considered strong enough to go on to the douches and baths.

Darwin then graduated to wet-sheet packing and the hot air bath, two of the most important treatments in Gully's extensive repertoire.

Wet-sheet packing (plate 11) had first been introduced into England by James Wilson, ${ }^{43}$ and was used by Gully for "lowering the energy of the brain", which in turn subdued the irritation of the stomach. ${ }^{44}$ It was thought to be a powerful sedative. A cold wet sheet was squeezed out and wrapped around the entire body; the patient lay on a bed or table and was further packed around with warm blankets, and left for

\footnotetext{
37 The charges for Gully's water cure are given in Wilson and Gully, op. cit., note 8 above, Prospectus, pp. 29-31. For patients who resided in Gully's establishment the fee was from four to five guineas per week, plus a weekly payment of $2 s .6 d$. to the bath servant; for patients who lived in lodgings the fee was reduced to two to three guineas, plus a weekly payment of $4 s$. to the bath servant. In either case there was an initial fee of two guineas for a consultation with Gully.

${ }^{38}$ Correspondence, op. cit., note 7 above, vol. 4, p. 225.

39 A shift in meaning documented by the Oxford English Dictionary. Henry Holland, Medical notes and reflections, London, 1839 , p. 362, considered that: "In dyspepsia, no symptom is better marked than the languid circulation of the blood through the extreme vessels"; Charlotte Brontë complained in a letter to Mrs Gaskell that "headache and dyspepsia are my worst ailments".

${ }^{40}$ Gully, op. cit., note 19 above, p. 127 . See also pp. 154-62.

41 Ibid., p. 85.

42 Correspondence, op. cit., note 7 above, vol. 4, p. 225.

${ }^{43}$ Metcalfe, op. cit., note 2 above, p. 61 . See also Wilson, The practice of the water cure, op. cit., note 19 above, which contains an account of the treatments used at Malvern.

44 Gully, op. cit., note 19 above, p. 159.
} 


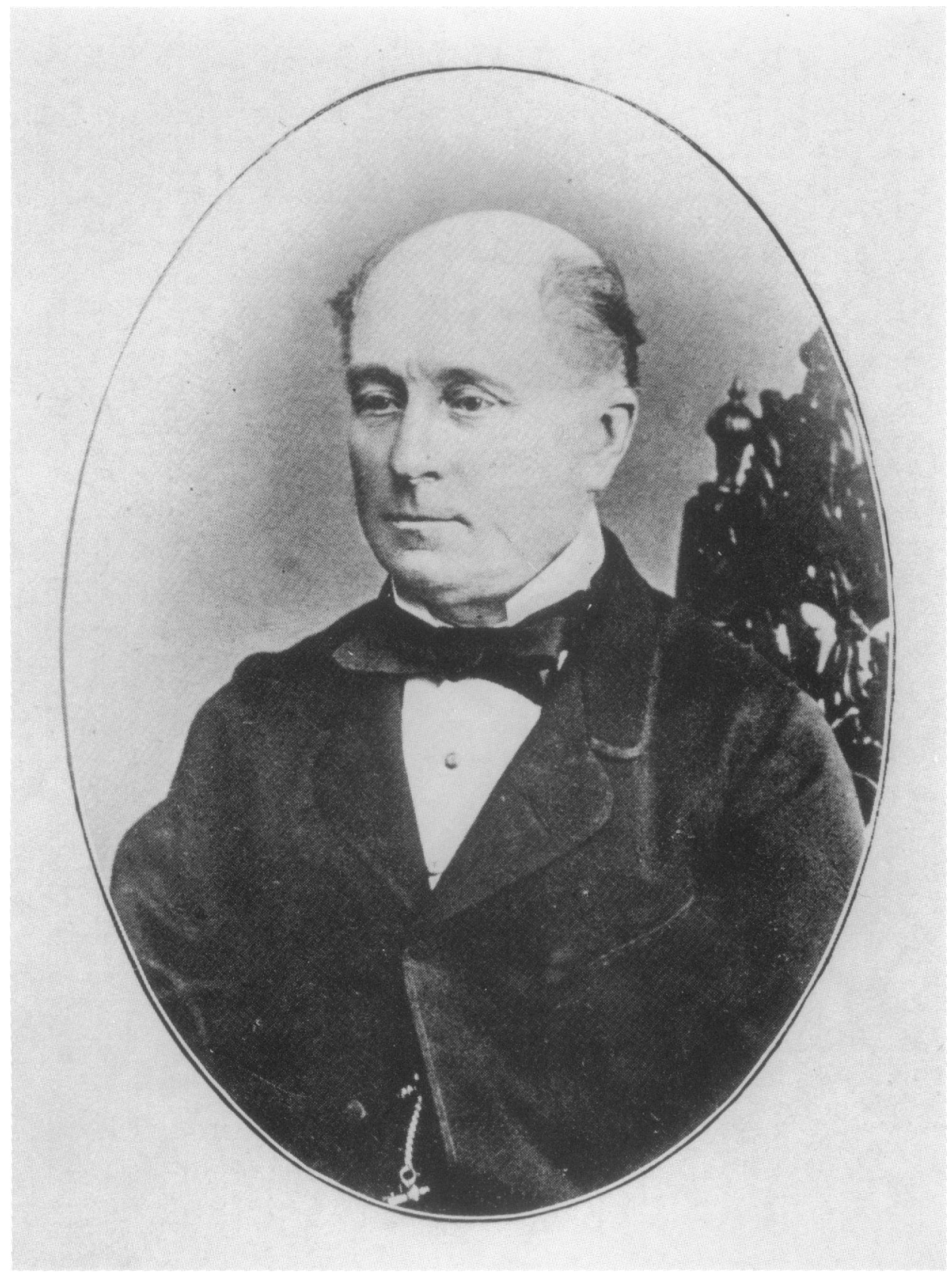

Plate 7: James Manby Gully. Photo: Wellcome Institute Library, London. 


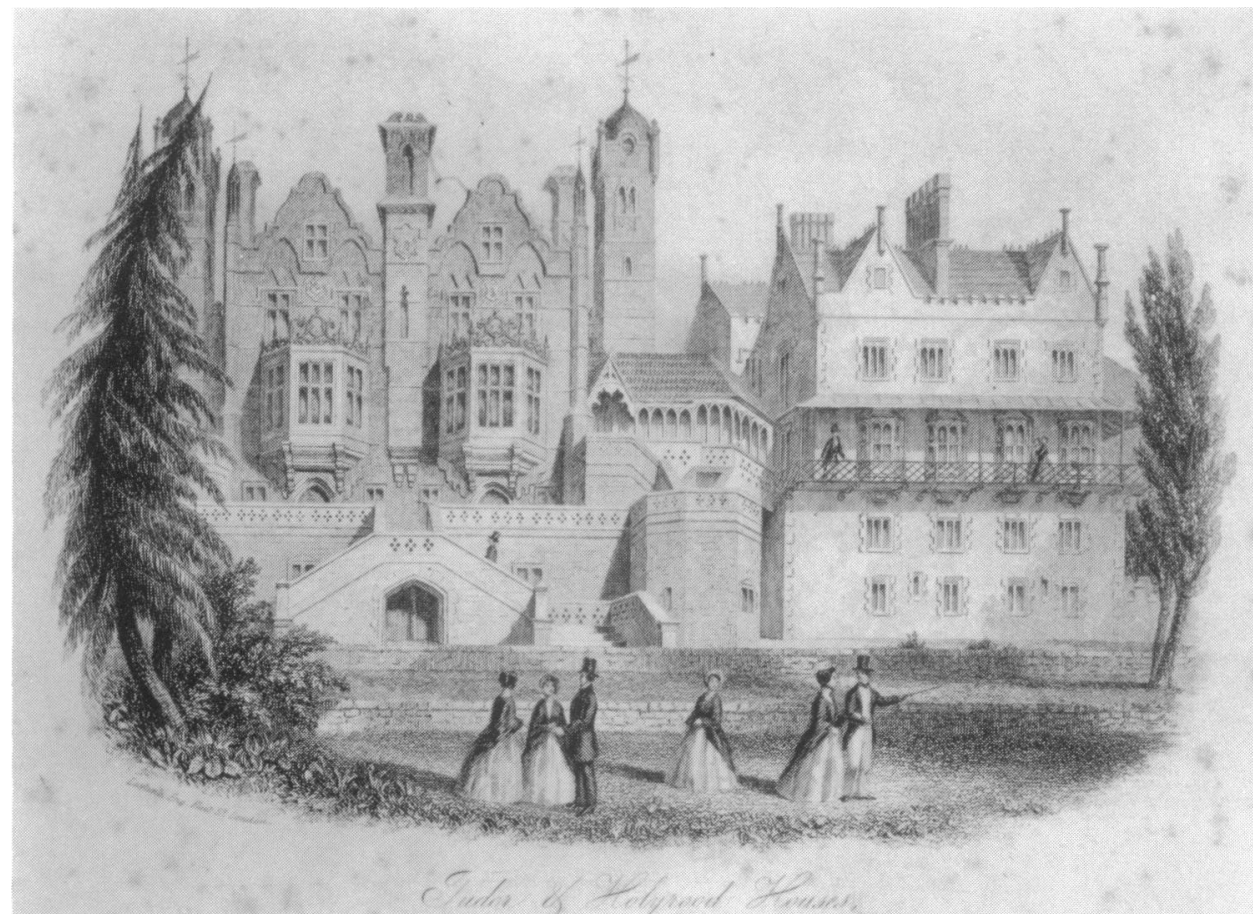

Plate 8: James Manby Gully's establishment. Tudor and Holyrood Houses were joined by a "bridge of sighs". Mid-nineteenth-century engraving published by H. W. Lamb, Royal Library, Malvern. Reproduced from the collection of Hereford and Worcester County Council, Malvern Library.

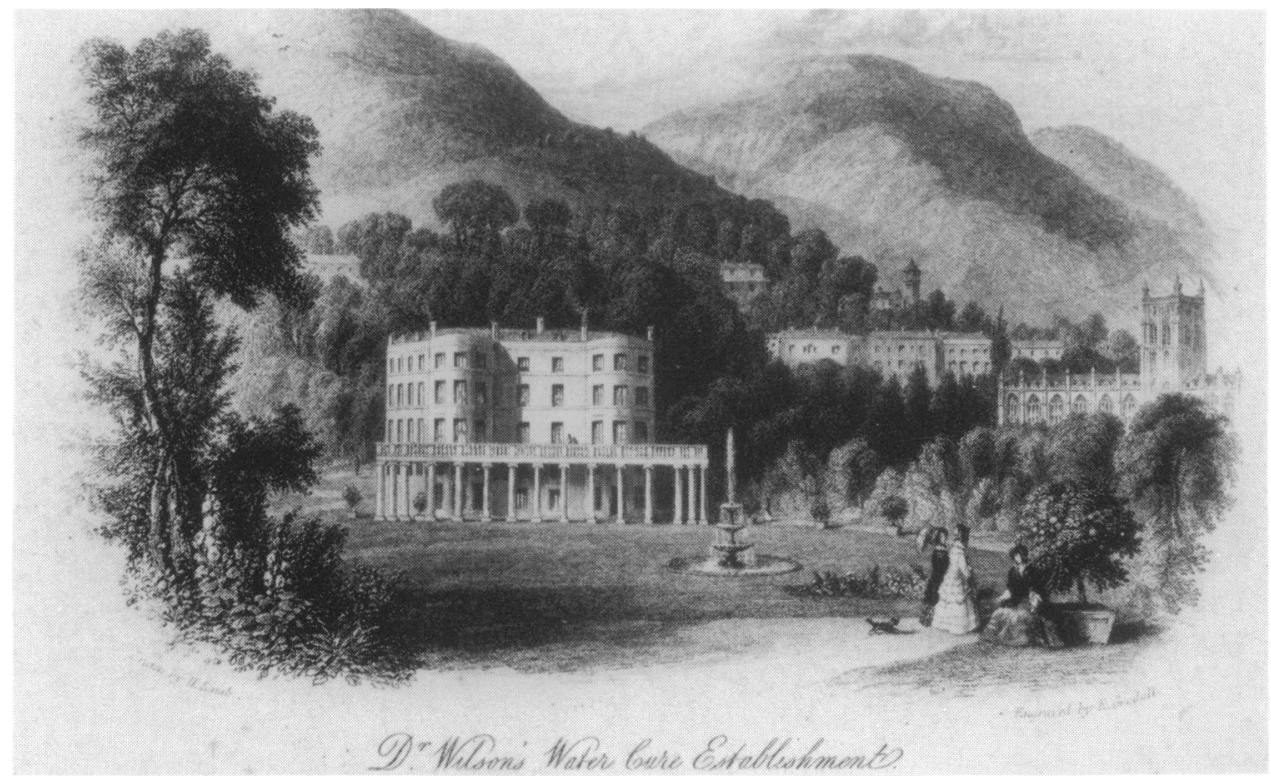

Plate 9: James Wilson's hydropathic establishment in Malvern. Engraving by E. Goodall after H. Lamb, n.d. Photo: Wellcome Institute Library, London. 


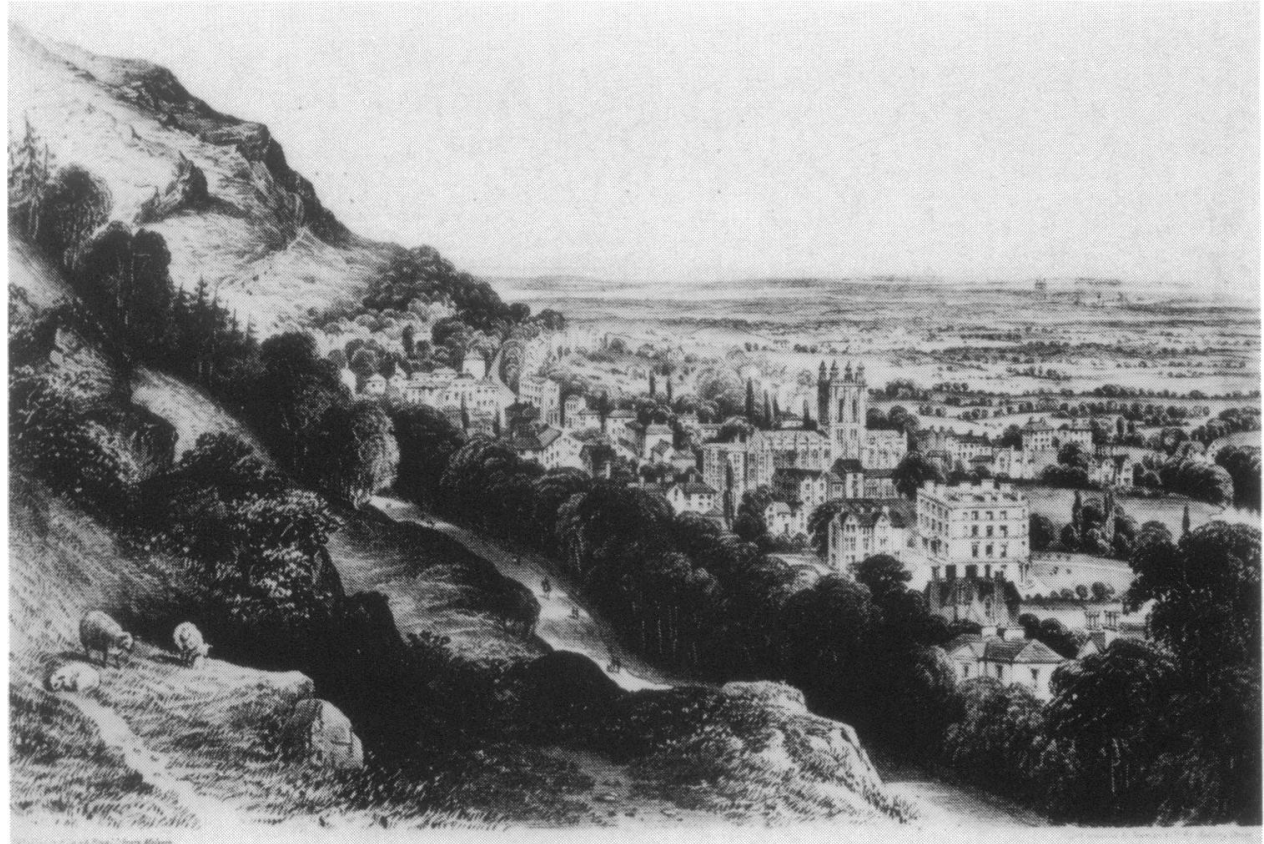

Plate 10: The walk up the Beacon in Great Malvern. Lithograph by Norman \& Co., published by H. Lamb, n.d. Photo: Wellcome Institute Library, London.

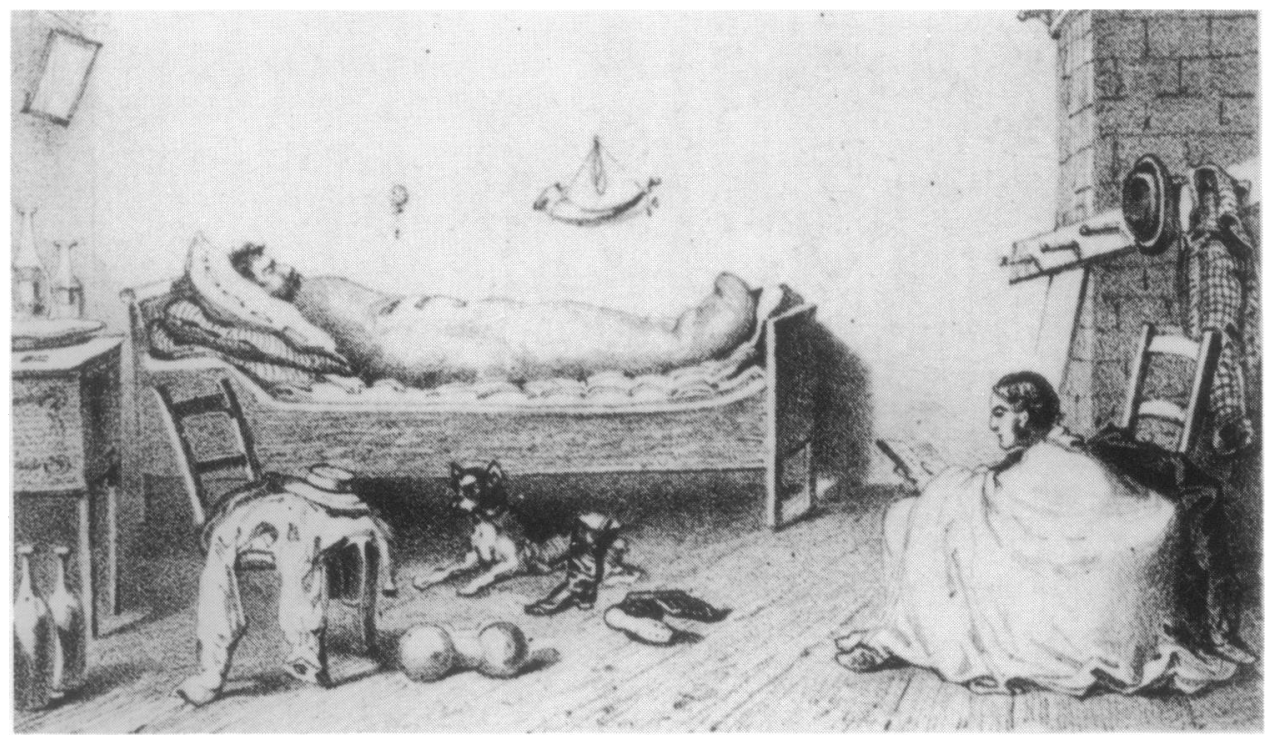

Plate 11: Gully and Wilson introduced Vincent Priessnitz's technique of wet-sheet packing in 1842. The patient on the left is packed in wet sheets and covered with several blankets. The patient on the right is in a shallow bath, draped with a wet sheet, and will soon be rubbed by an attendant as in plate 13. The illustrations (plates 11-16) are from a series of lithographs illustrating Priessnitz's regimen, c. 1830. Photo: Wellcome Institute Library, London. 


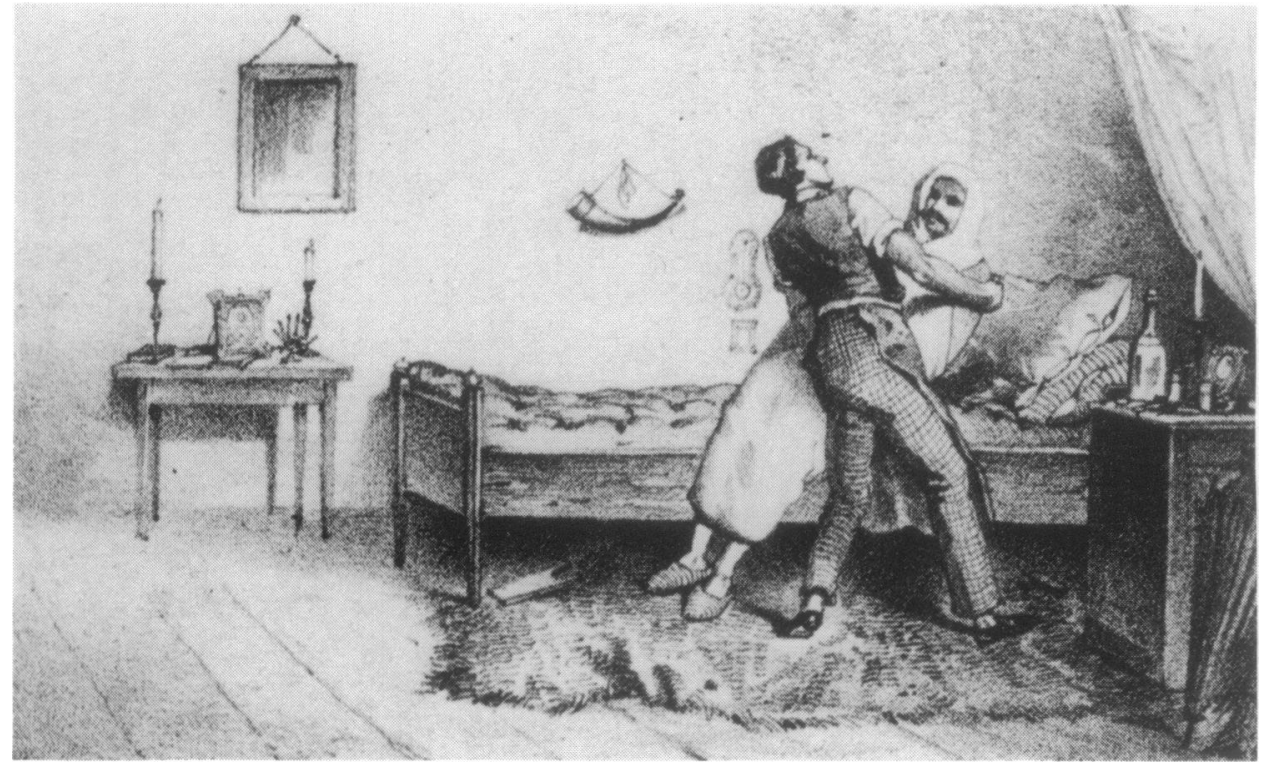

Plate 12: Unpacking the patient. Photo: Wellcome Institute Library, London.

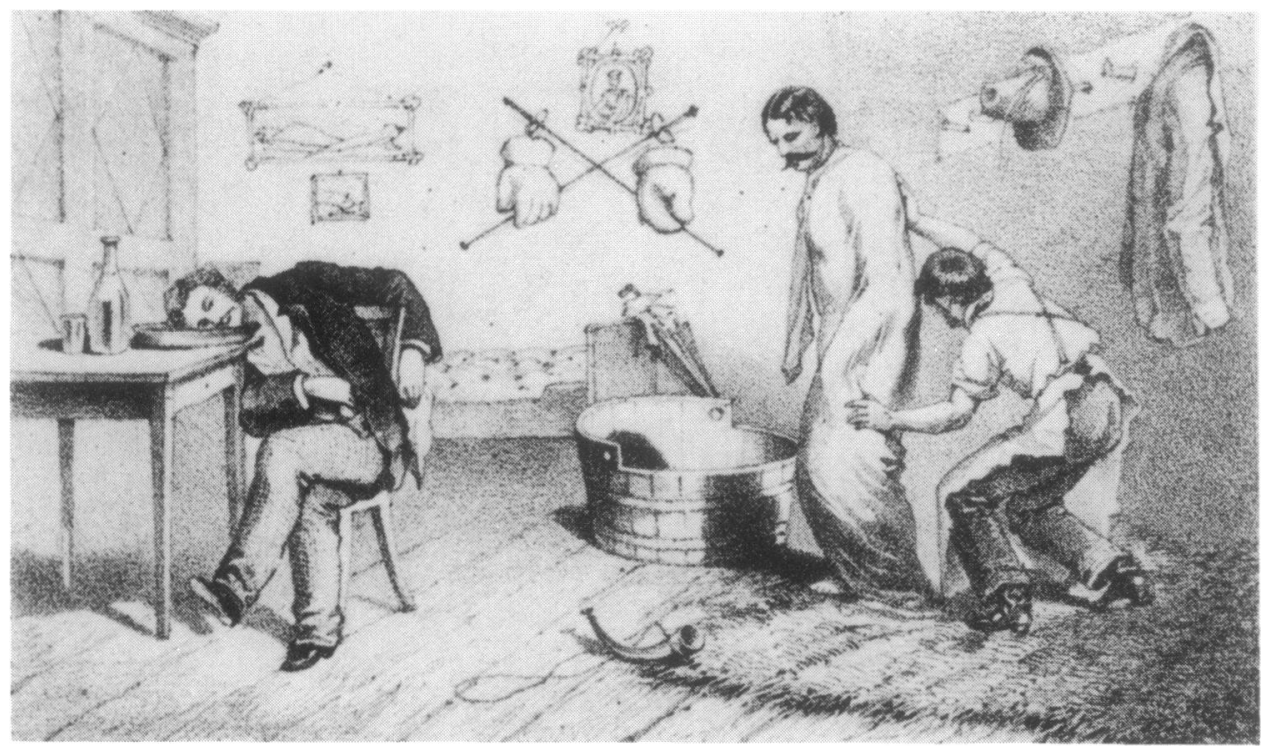

Plate 13: The scene on the right shows the dripping sheet in use. A bath attendant rubs the patient vigorously through the wet sheet. The patient on the left is treating his face with cold water. Photo: Wellcome Institute Library, London. 

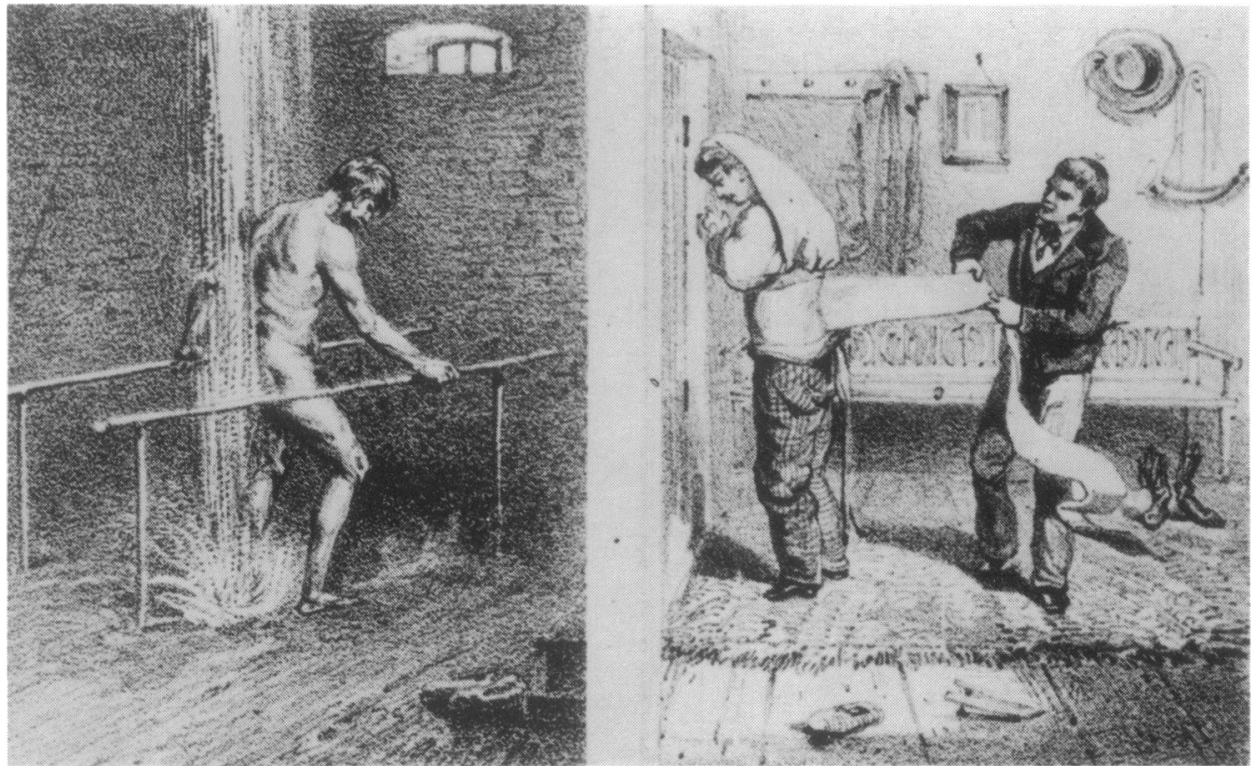

Plate 14: A stomach girdle (right) was used by Darwin when undergoing treatment at Malvern. The wrappings were worn damp, underneath a waterproof "Mackintosh" covering. Cold showers (left) were an essential part of the daily regime. Photo: Wellcome Institute Library, London.

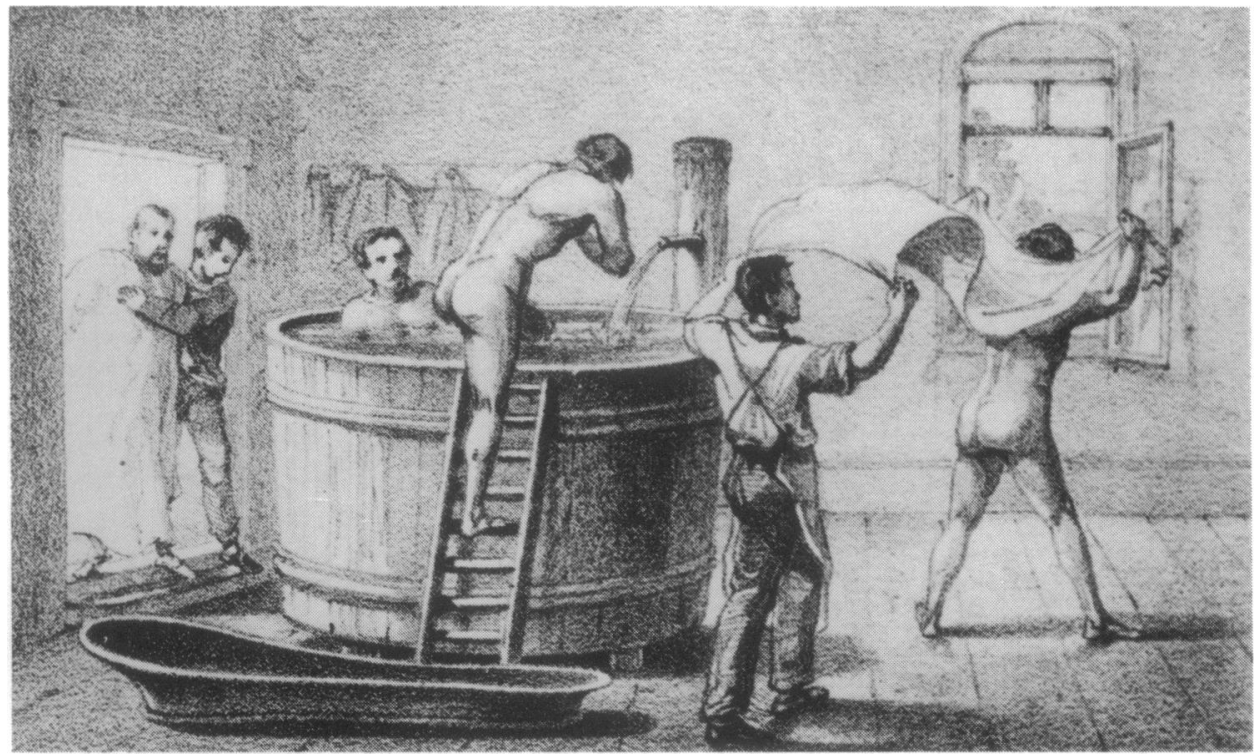

Plate 15: The wooden bath of Priessnitz's system was duplicated in Gully's establishment in Malvern, but there is no evidence that the airbath was similarly used. Photo: Wellcome Institute Libary, London. 


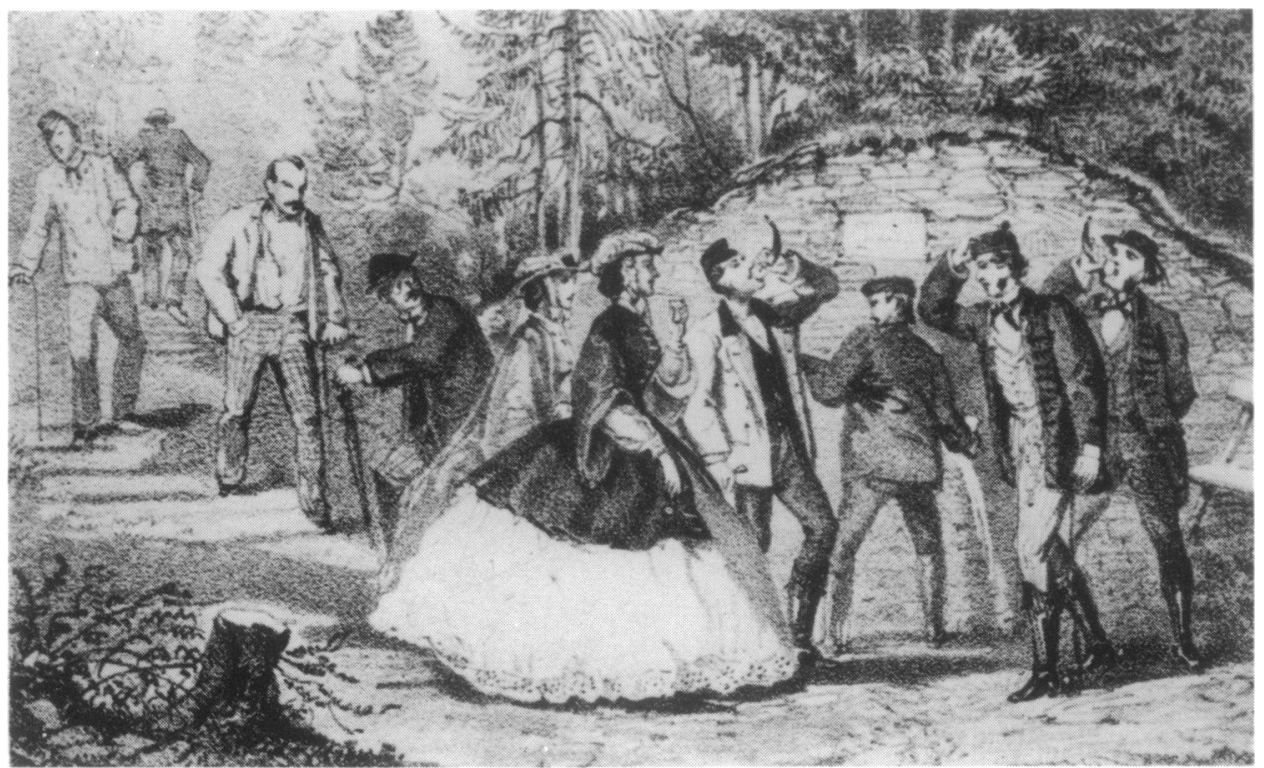

Plate 16: The routine of walking to a well or drinking fountain was a central feature of Priessnitz's treatment. Photo: Wellcome Institute Library, London.

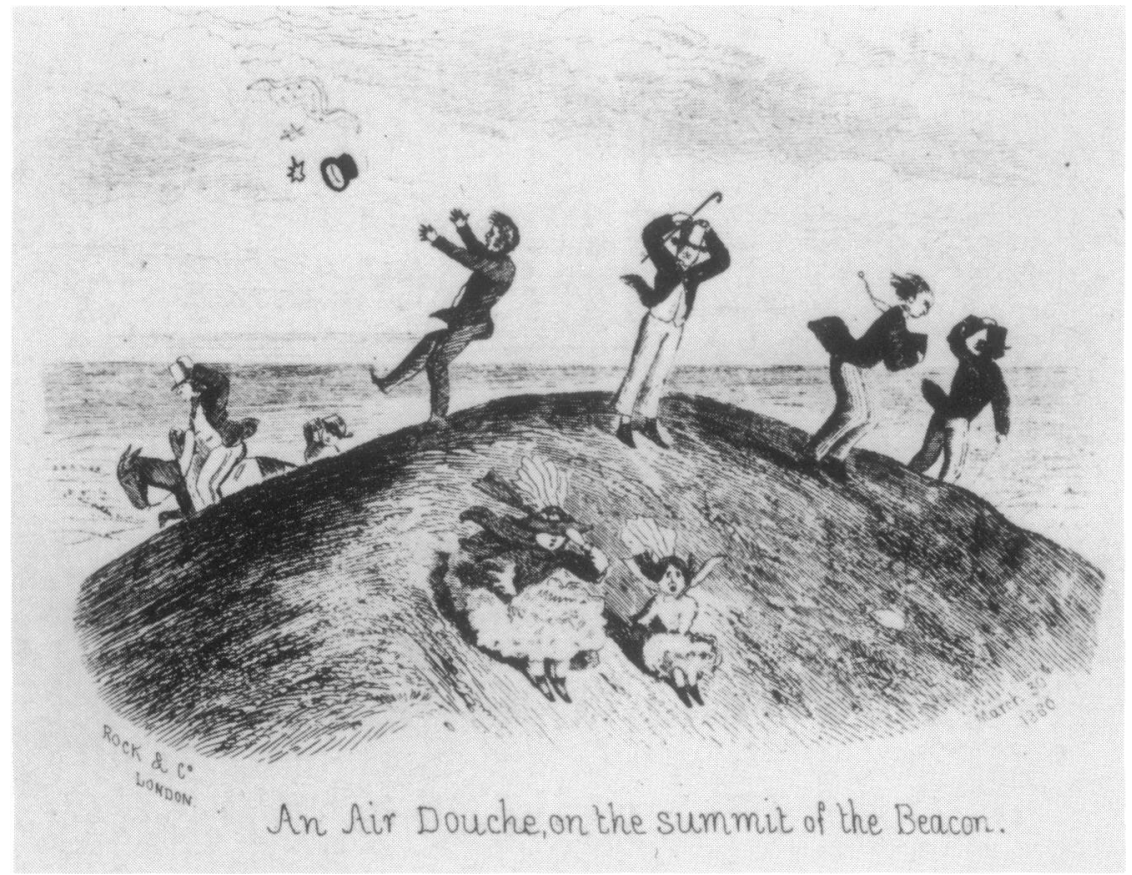

Plate 17: Gully insisted that his patients took regular exercise and fresh air. Wood engraving by Rock \& Co., London, March 1860. Photo: Wellcome Institute Library, London. 


\section{Darwin at Malvern}

about an hour, while the wet sheet drew out impurities. Much the greatest benefit was apparently derived from the energizing effect on the skin and circulation.

The wet-sheet treatment was always followed by some external application of water, such as a shallow sponge bath, a towel rub, or, in Darwin's case, by what was called the dripping sheet. After unwrapping (plate 12), it was thought essential to tone up the skin by rubbing: ${ }^{45}$ the dripping sheet was, as its name suggests, a wet sheet draped over the body, through which the patient and the bath attendant rubbed the skin vigorously. The process was repeated two or three times with the sheet being more and more saturated with water. It ended with a dry sheet being similarly rubbed over the body. Alternative ways of applying the dripping sheet were to use it whilst sitting or standing in a hip bath (plates 11 and 13).

In some cases, and Darwin was again one of these, the dripping sheet was used in combination with another technique as an alternative to the baths or showers. This was the lamp, or perspiration bath, one of Gully's own introductions ${ }^{46}$ and soon modified and popularized as an air or steam bath by another hydrotherapist in Malvern, Dr Ralph Grindrod. 47 "At present," wrote Darwin, "I am heated by Spirit lamp till I stream with perspiration, \& am then suddenly rubbed violently with towels dripping with cold water: have two cold feet-baths, $\&$ wear a wet compress all day on my stomach." However absurd it sounded, as he assured his friend Joseph Hooker, "I feel certain that the Water cure is no quackery."48

Darwin's therapy soon moved into the more usual routine of regular showers, baths, and the application of various forms of sheets and compresses. He had a stomach girdle that was removed before meals but otherwise worn all day (plate 14, right). He took extremely cold showers (plate 14, left). He took communal baths, like the others (plate 15); but he probably did not experience the airbath (also shown in plate 15), for there is no record of Gully or of Wilson ever recommending this particular form of therapy, although Priessnitz thought highly of it. ${ }^{49}$

At Malvern, air was a form of therapy to be sought outside. Gully's insistence on exercise, usually taken in the form of frequent short walks through the day, was the butt of most patients' jokes. Unlike the treatment at Graefenberg, the object of these walks was not to make one's way to a mountain spring or well-head and there to take the healing waters (plate 16). Drinking the waters was never a significant part of Gully's therapeutic regime. The point for Gully was solely the exercise and fresh air. He sent his patients up to the top of the Beacon four times a day, amounting to an energetic daily quota of seven miles, half of it steeply uphill (plate 17).

Darwin complained he had been turned into a mere walking and eating machine by the end of his stay, and other visitors, like Dickens, ${ }^{50}$ found the sheer number of walkers and their air of purpose all too much to take (figure 1).

45 Ibid., p. 599.

${ }^{46}$ Metcalfe, op. cit., note 2 above, p. 73.

47 W. H. McMenemey, 'The water doctors of Malvern, with special reference to the years 1842 to 1872',

Proc. R. Soc. Med., 1952, Section of the History of Medicine, 46: 1-8.

48 Correspondence, op. cit., note 7 above, vol. 4, p. 227.

${ }^{49}$ Richard Metcalfe, Life of Vincent Priessnitz, founder of hydropathy, London, 1898.

50 Cited in Turner, op. cit., note 1 above, p. 168. 


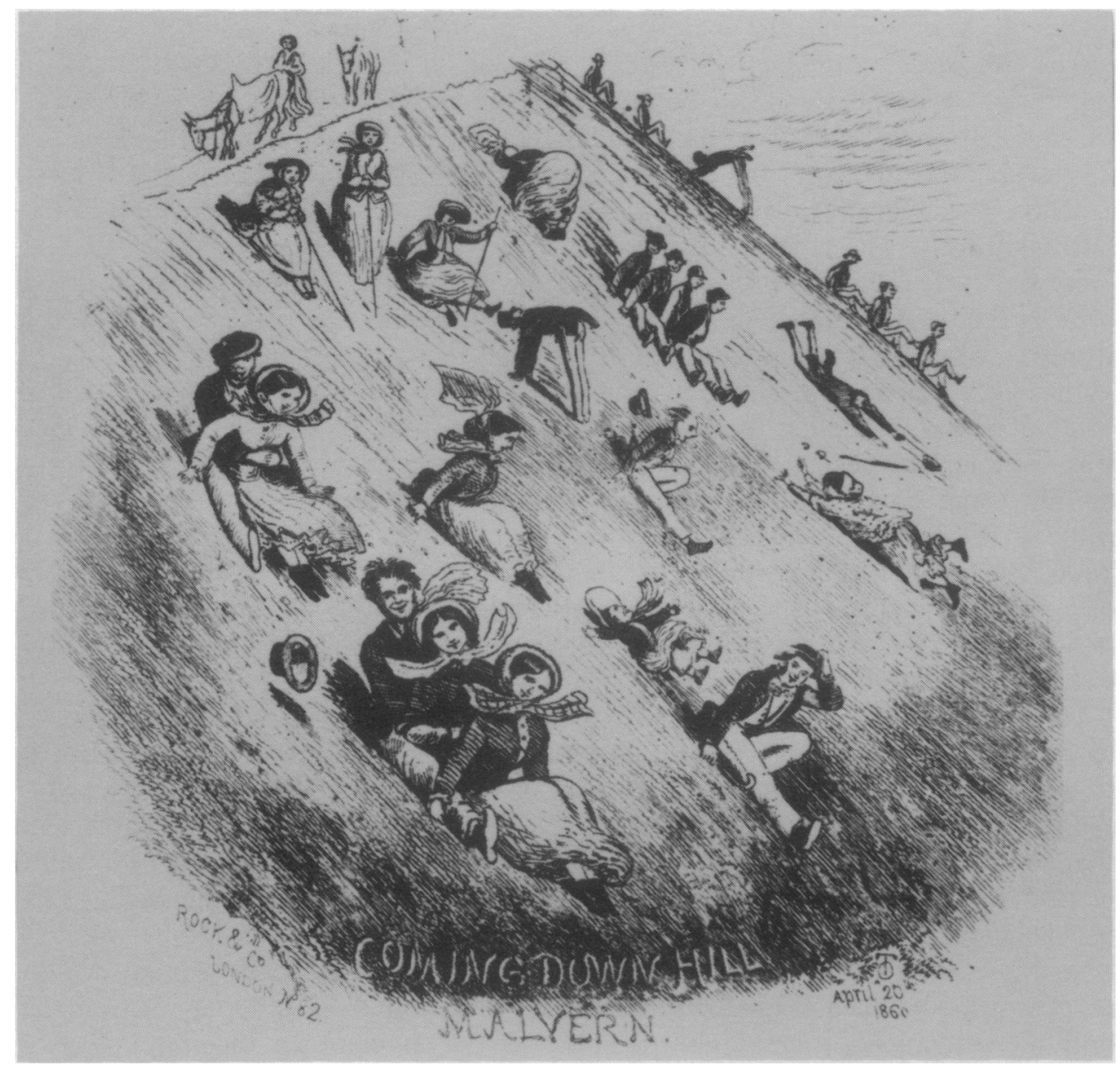

Figure 1: Wood engraving published by Rock \& Co., London, April 1860. Photo: Wellcome Institute Library, London.

After three months of therapy, Darwin felt that he really had improved. He reported to his cousin Fox that he had put on weight, had not felt sick for 30 days in succession, and that Gully had succeeded in relaxing his nervous system so far that he now felt indolent and stagnant. ${ }^{51}$ And even though Gully insisted he could not bring about an actual cure for any chronic disorder in less than six months. ${ }^{52}$ Darwin was sticking to his original plan and returning to Down and his beloved barnacles for the summer. ${ }^{53}$ Gully was evidently used to patients leaving Malvern when they wished rather than following his instructions to the letter: he gave Darwin a comprehensive

51 Correspondence, op. cit., note 7 above, vol. 4, p. 234.

52 Gully, op. cit., note 9 above, p. 167.

53 Correspondence, op. cit., note 7 above, vol. 4, p. 246, in which Darwin told his cousin Fox that they had stayed at Malvern for sixteen instead of six weeks. 


\section{Darwin at Malvern}

outline of treatment that could be performed at home and recommended a suitable interval before making another visit to Malvern. Darwin did indeed follow Gully's advice $^{54}$ and built for himself an outdoor douche and bath in the garden at Down, ${ }^{55}$ which his son George considered was something very like a diminutive church, and which was in daily use for about five years, ${ }^{56}$ with Parslow, the butler, in attendance, having learnt how to do all the rubbings and sluicings whilst he was with the family at Malvern in "The Lodge". 57 Darwin also followed Gully's dietary rules to the best of the household's ability. ${ }^{58} \mathrm{He}$ bought a horse to exercise on ${ }^{59}$ and took up the regular routine of several turns around the sandwalk at the bottom of his garden at set intervals during the day. Moreover, he settled down with resignation to Dr Gully's recommended timetable of only two and half hours of hard mental activity per day. ${ }^{60}$ For, as he reported to his cousin, "with respect to myself I believe I am going on very well." 61 Writing to his old friend and former professor at Cambridge University, John Stevens Henslow, he was confident that the cure "has answered to a considerable extent: my sickness much checked and considerable strength gained." ${ }^{26}$ Four weeks later, in June 1849 , he still believed that it had wrought "an astonishingly renovating action on my health". ${ }^{63}$ Darwin did not feel himself cured but considered that he had found a possible route to health if he persevered with his treatment.

Darwin subsequently visited Malvern four more times, two of the trips being in the following 12-month period. These were, however, only for brief consultations. The last extended visit came when his eldest daughter, Anne, fell seriously ill in the autumn of 1850. Both Darwin and Emma agreed that perhaps Anne might benefit from the water-cure, particularly as Darwin suspected that her disorders were similar to his own, and probably, as Henry Holland put it, an hereditary taint. 64 "She inherits I fear with grief, my wretched digestion" wrote Darwin to Fox. ${ }^{65}$ And, as they also knew, Gully regularly treated children. But the tragedy of this particular stay in Malvern, made during the early months of 1851, was that Anne died under Gully's care, succumbing to some wasting fever while Darwin watched helplessly. Emma Darwin was not there, for she was confined to Down, due to give birth again in May 1851. Darwin returned alone, having arranged to bury the little girl in Malvern churchyard. ${ }^{66}$ Emotions ran too deep to attend the funeral.

54 Ibid., pp. 234, 240.

55 Ibid., pp. 246, 335.

56 Ibid., pp. 353, 354 n. 2.

57 Francis Darwin, ed., The life and letters of Charles Darwin, 3 vols., London, John Murray, 1887, vol. 1, p. 131.

${ }^{58}$ Emma Darwin's recipe book (DAR 214, Darwin archive, Manuscripts room, University Library, Cambridge) indicates that bland, nursery-style food was served at Down House.

59 Correspondence, op. cit., note 7 above, vol. 4, p. 240.

${ }^{60}$ Ibid., pp. 266, 309, 310.

61 Ibid., p. 234.

62 Ibid., p. 235.

63 Ibid., p. 239.

64 Holland, op. cit., note 39 above, p. 16, with reference to the transmission of morbid products possibly by blood.

${ }^{65}$ See Correspondence, op. cit., note 7 above, vol. 5, p. 9.

${ }^{66}$ See ibid.; Ralph Colp, 'Charles Darwin's "insufferable grief” ', Free Associations, 1987, 9: 7-44; James R. Moore, 'Of love and death: why Darwin "gave up Christianity" ', in idem (ed.), History, humanity and evolution: essays for John C. Greene, Cambridge University Press, 1989, pp. 195-229. 


\section{Janet Browne}

Rather surprisingly, Darwin did not lose faith in either Gully or his water-cure. But he could not bear to visit Malvern again until 1863. After Anne's death he drifted towards another practitioner, Edward Wickstead Lane, in an establishment at Moor Park, in Surrey, quite close to where his sister Caroline then lived. As far as we know, he kept faith with the therapy for at least another 12 years, retreating to Dr Smith at Ilkley Wells when the Origin of species was published, and to Dr Ellis at Sudbrook Park during the British Association controversy in 1860, even allowing his next surviving daughter Henrietta to take the cure at Moor Park, before reluctantly abandoning it amid a welter of new symptoms in 1864 or so.

Looking back over Darwin's experience of hydrotherapy, there are two issues that seem worth some future attention, not necessarily in relation to Darwin, but as a general way into assessing what the water-cure may have meant to its actual patients and visitors. Darwin quite plainly considered the cure as something that could be tried - as a system of treatment that was made available by water-doctors but which was chosen by patients. The high profile of the patients themselves in these patient-doctor relationships was further emphasized by the way that the clients decided how much of the treatment to incorporate into their daily routine and the appropriate length of stay. The continuation of treatment at home or at another establishment were also questions ultimately resolved by the patient.

But this is not entirely unexpected in the history of spas. Where the mid-nineteenthcentury water-cures seem to be different from earlier therapeutics is in the kind of disorders they claimed to treat and in the kind of people who went for treatment. Although Gully and Wilson were themselves outspoken medical reformists, ${ }^{67}$ operating on the fringes of traditional practice, few of their patients necessarily travelled along the same road. Darwin was neither crank nor radical. His social and medical beliefs were certainly rooted in the liberal end of the established order of early Victorian society, but he took up the water-cure only when conventional medicine failed him. Gully catered precisely for this market, drawing his clients from the prosperous middle ranks of the community, or higher, if possible, scrupulously avoiding both the working poor and those likely to be therapeutic extremists.

Gully's diagnostics were similarly attuned to the needs of his customers. Like Darwin, many of the Malvern patients considered themselves to have "nervous" diseases: Thomas Carlyle had nervous dyspepsia; ${ }^{68}$ Charles Reade, the novelist, had a nervous breakdown, ${ }^{69}$ as did Tennyson for a second time in $1848 ;^{70}$ Charles Dickens reported that his wife "has a nervous illness about her"; 71 Edward Bulwer-Lytton was

\footnotetext{
${ }^{67}$ McMenemey, op. cit., note 47 above; Price, op. cit., note 23 above. See also J. M. Gully, The simple treatment of disease deduced from the methods of expectancy and revulsion, London, 1842.

${ }^{68}$ Charles Eliot Norton (ed.), The correspondence of Thomas Carlyle and R. W. Emerson, 1834-1872, 2 vols., London, 1883, vol. 2, pp. 205-7; James Lorimer Halliday, Mr. Carlyle my patient: a psychosomatic biography, London, William Heinemann, 1949.

69 Compton Reade, Charles Reade, dramatist, novelist, journalist; a memoir, compiled chiefly from his literary remains, 2 vols., London, 1887, vol. 1, pp. 308-13; John Coleman, Charles Reade as I knew him, London, Treherne \& Co., 1903, pp. 93-4.

${ }^{70}$ Martin, op. cit., note 14 above, pp. 276-81.

71 Walter Dexter (ed.), Dickens to his oldest friend: the letters of a lifetime from Charles Dickens to Thomas Beard, New York, Haskell House Books, 1973, p. 141. Also cited in House and Storey, op. cit., note 15 above, vol. 6 , p. 342.
} 
weighed down with nervous fatigue. ${ }^{72}$ These were felt to be the disorders of great men and their spouses: disorders emanating from hard intellectual struggle, from overwork, from nervous exhaustion. "What time was not given to action was given to study; what time not given to study, to action-labour in both! .. . The wear and tear went on without intermission - the whirl of the wheel never ceased" wrote Bulwer in anguish. ${ }^{73}$ Darwin and others surely came to Gully because his therapy was based on the attractive idea that excessive intellectual activity could lead to a breakdown in nervous health. The system of water-based techniques for stimulating the circulation was held out to these patients as a direct route to the soothing of shattered nerves. It therefore seems quite clearly the case that the sensibilities and priorities of the nineteenth-century water-patient at Malvern, and probably elsewhere too, were completely different to those of the frivolous society-seeking habitués of the spas of the previous century. Malvern patients believed their complaints emerged from a personal struggle with the stresses of contemporary intellectual existence rather than from self-inflicted dissipation or over-indulgence, and that their customary mental vigour would best be restored, not by rest and relaxation in the company of friends at an elegant Georgian spa, as their grandparents and parents had so evidently enjoyed, but by an energetic physical regime that directly catered for the repair of what were at that time held to be the prodigious intellects of overworked, broken-down eminent Victorians. "I foresee, this 'water cure' under better forms, will become the Ramadhan of the overworked unbelieving English in time coming," prophesied Carlyle from his wet sheets in Malvern; "an institution they were dreadfully in want of, this long while!"74

\footnotetext{
${ }^{72}$ Bulwer-Lytton, op. cit., note 16 above, pp. 9-19.

${ }^{73}$ Ibid., p. 12. On the general outlook and origins of the "nervous patient" see W. F. Bynum, 'The nervous patient in eighteenth- and nineteenth-century Britain: the psychiatric origins of British neurology', in W. F. Bynum, R. Porter, and M. Shepherd (eds.), The anatomy of madness: essays in the history of psychiatry, vol. 1, People and ideas, London, Tavistock, 1985, pp. 89-102.

${ }_{74}$ Norton, op. cit., note 68 above, vol. 2, p. 206.
} 